\title{
A Global Perspective on Racial and Linguistic Integration in South African Christian Congregations
}

Dr. Dawid Venter

Table of contents

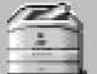

Printer Friendly HTM

Joumal of World-Systems Research, Vol V, 3, 1999, 619-650

$\underline{\text { htt.p://jwsr.ucr.edu/ }}$

ISSN 1076-156X

1999 Dawid Venter

\begin{abstract}
This is a study that uses data from a national survey of multicultural and multilingual Christian congregations in South Africa to examine the institutional factors that support the dominance of English in formerly segregated churches without a formal language policy. Data were collected by qualitative methods on the levels and types of linguistic integration (as well as racial and cultural incorporation) in each of 60 congregations from nine Christian denominations across South Africa. The patterns found are best explained in terms of the articulation of formal and popular ideologies that contribute to institutional isomorphism across state and civil institutions.
\end{abstract}

\section{INTRODUCTION}

One of the most notable effects of the apartheid state was to segregate all major institutions legally, resulting in an enforced and almost total residential and social segregation between 1948 and 1990 . Contact between race groups was extremely limited, usually to formal work environments; while linguistic diversity was dampened under a bilingual language policy which favoured English and Afrikaans.

Currently South Africa's new, post-1994 regime endorses non-racialism and implicitly as twin national ideologies underpinning its frequent exhortations to nation-building. Nonracialism encourages racial integration within the same institution across all sectors of society, from educational to economic, most notably in the affirmative action quotas of the recently passed Labour Equity Bill. Multiculturalism emerges in the recognition of eleven official languages in the new 1996 Constitution, in contrast to the two official European-derived languages of the past (English and Afrikaans). The preamble of the 1996 Constitution also implicitly recognises the rights of all South Africans to practice their languages and cultures. Concretely, people are drawn toge ther into settings and relations which previously were ideologically and geographically difficult to structure, where they can renegotiate or discard ascribed and enforced identities, such as race or language. 
There is some evidence that the state's formal multilingual policy conflicts with an existing informal monolingual language ideology. This would explain why the evidence in the public sector is so ambivalent, a subject I referred to elsewhere (Venter 1996). Official encouragement of multilingual diversity is often denied in practice, with English achieving hegemony in Parliament and Senate by 1996, in provincial-national government communication, as well as in many local government meetings (Langtag 1996:47). A Siswati-speaking Constitutional Assembly official reportedly said that "we in the ANC do not believe in ethnic languages" (Leadership 14:2, p.13).

An audit by the Language Plan Task Group (Langtag) in 1996 of the annual reports by government departments found that only two departments published multilingual reports (Communication Services, Justice); seven bilingual (English and Afrikaans); and twelve used English only. In addition many other Government publications were published in English only, including general notices (e.g. relating to the restitution of Land Rights Act in 1995) and White Papers (like the Reconstruction and Development Programme of 1994) (Langtag 1996:159-161). In the tertiary education sector Afrikaans-speaking universities have in the past come under pressure to switch to English from nonAfrikaans-speaking students and from the Minister of Education, Professor Sibusiso Bhengu.

The option for a former colonial language places language practice in South Africa within a pattern well established across Africa by elites, who tend to favour European languages above indigenous ones (Prah 1993). While most African states are exoglossic, dominated by European languages (English, French, Portuguese) as the national language - yet European languages are usually spoken by a small elite comprising "fewer than 20 per cent" of the population (Kaschula \& Anthonissen 1995:102,103). Endoglossic states include Tanzania (Swahili), Somalia (Somali), Ethiopia (Amharic), Sudan (Arabic), and Guinea (with eight languages such as Fula, Manding). Other states which have indigenous official languages, but which do not actively promote their use, include Botswana (Tswana), Burundi (Rundi), Lesotho (Sotho), Malawi (Chewa), Rwanda (Kinyarwanda), and Swaziland (siSwati) (Kaschula \& Anthonissen 1995:102).

South African Christian churches were just as affected by apartheid as other social institutions, with few exceptions. Despite an initial ideal of racially-mixed services expressed by most denominations from the 17th to 19th centuries in the first colonised region of South Africa (the present Western Cape), racially-integrated congregations are rare in South Africa today. Although vocally opposed to legislated discrimination, the English-speaking churches generally exhibited a pragmatic compliance with racial segregation. By 1964, Anglicans, Methodists, Catholics, and Presbyterians admitted that "people of different races do not normally worship together in the same church" (Cawood $1964: 58,61,52,76,92)$. Segregated congregations became the rule well into the $1980 \mathrm{~s}$, with the only exceptions often being cathedrals in large cities. Significant sections of the 
mainline churches were labelled as English-speaking or Afrikaans-speaking - despite other language groups forming majorities in these denominations.

The central concern of this article is with language usage in racially and linguistically diverse congregations; with what the choice of language/s reveals about the relations between language groups; and with how this configuration can be explained through new institutionalism. I am interested in how religious institutions are affected by extrainstitutional factors which function at national and global levels. For this reason I examine language choice in a voluntary organisation without a formal language policy, as providing an ideal setting in which to demonstrate the effect of meso- and macro-factors.

As part of religious institutions in a secular state, multicultural and multilingual Christian congregations fall outside direct control of the state as far as language preference is concerned. Theoretically the language used in services (e.g. English, Zulu) is much more open to negotiation than those used in the public sector organisations. At the same time churches are not unconnected to other dynamics and institutions, and their members do not leave either ideological persuasions or social identities at the door, thus importing external dynamics into the decision-making of congregations. Others have examined integrating congregations (Massie 1993), as well as race and language at the denominational level (Kritzinger 1995, Zaaiman 1994). Yet mine is the first attempt to specifically examine language usage in South African congreg ations, as far as I am aware.

Of special import in this article is how language preference links to the perceptions and interrelations between groups of people. First, language preference (i.e. which language one chooses to speak) is not necessarily a neutral option, but often co-occurs with contestations of power. Second, language preference is a function of a language ideology, which determines the attitudes of different language groups towards one another, as well as structuring relations between groups in a status hierarchy. Third, language usage as part of a social identity is largely dependent on the institutional setting within which it takes place. The type of setting, in conjunction with the ideology, determines specific types of representation, with certain linguistic identities deemed appropriate and others not.

In what follows below I will first clarify some terms and briefly outline the methods used to obtain the data which forms the basis for this discussion. Then I supply a summary of the distribution of language and race groups within the three denominations relevant to this study, in the context of a brief social history of the emergence, development, and current state of segregation and integration within these. This overview leads to a description of the data, followed by a analytical discussion. Finally, I close with some concluding comments.

\section{TERMINOLOGY}


Language refers to the vernacular of a particular (ethnic) speech-community, i.e. English, Afrikaans, Zulu. Race was retained because it remains an operational social construct in the South African context, despite ideological and technical problems involved. While race has no scientific merit, it continues to affect social relations. Racial composition adds a different dynamic to the functioning of a congregation or denomination, and so is worthy of isolation (see De Gruchy 1986:246). I am convinced that a focus on race is essential to expose overt and covert racist patterns of behaviour.

For purposes of argument I distinguish between integrating and integration as follows:

a. Integrating is used in a general sense to refer to congregations which display some (unspecified) level of linguistic and racial diversity, and which are presumably still undergoing this process. Congregation refers to the average number of those people (i.e. the "congregants"), no longer of school-going age, who attended all services on all Sundays during March 1997 for the purpose of participating in Christian worship.

b. Integration refers to the incorporation of differences at two levels in answer to the questions: "Are any differences present", and "How were these differences included?". I operationalize integration at the general level of congregational membership (number of race and language groups present), and at the specific level of congregational leadership (representativeness of race and language groups).

The implication is that an integrated congregation will be a type of mixed congregation that has a (relatively) stable racial/ethnic mix, in which the diversity of members is represented at all levels of decision-making, and allowed to affect the content and structure of the service. In this sense integration proceeds from "a recognition of a racially and culturally pluralistic society ... in which cultures, languages, and races interrelate so as to bring strength, depth, and diversity to the whole. Integration should not mean, or require, the giving up of one's accent, songs, or life-style, but it can be the framework in which diversity is shared and appreciated by all" (Davis \& White 1980:100).

\section{THEORETICAL ORIENTATION}

My study falls, broadly speaking, within the political sociology of language, which addresses language and power as central issues. I refer to the forms through which language and power are mediated (e.g. political ideology, culture, language ideology) as well as the outcomes (e.g. hegemony). Politics "concerns the exercise of power in social situations, its structuring, as well as its legitimation within social groups" (Goke-Pariola 1993:7). The "politics of language necessarily involves relations between languages" (Fardon \& Furniss 1994:6). 
The focus of a political sociology of language articulates with discourses on language choice, language planning, language policy, and language use. In a narrow sense the emphasis is on "rule-making and rule enforcing activities" of sociolinguistic groups within certain domains, and in a broader sense on "the patterned co-variation of political and social behaviour on the one hand, and language behaviour and use on the other" (Goke-Pariola 1993:7). The narrower focus relates to "who speaks what language/dialect to whom, and when, and what are the consequences of breaking the sociolinguistic rules". The broader emphasis is on how, who or what produces the conventions that determine the "expressive resources" available to particular groups or languages (Goke-Pariola 1993:7).

New institutionalism is not a unified approach, but takes rational choice, historical, and sociological forms, which are employed somewhat differently by economists, political scientists, and sociologists (Cook \& Levi 1990; Koelble 1995; Hall \& Taylor 1996; Lowndes 1996; Hirsch 1997; cf. Sjostrand 1993:6; Granovetter \& Swedberg 1992). My focus is on relevant components of new sociological institutionalism, in which institutions (including "conventions and customs") are viewed as dependent on macro factors such as culture and society; i.e. institutions are dependent variables which determine individual actions (Koelble 1995:232,234). Actors choose actions based on their institutionally-guided perceptions of appropriateness within a particular context (Koelble 1995:234). Individuals are embedded in so many relationships that utilitymaximising and rational explanations becomes almost impossible. Organizations choose particular cultural or symbolic systems "which are then reflected in the structures, functions, and goals of the organisation as well as the rationality of individuals within the organisation and institution" (Koelble 1995:235).

As a major concept within new institutionalism, institutional isomorphism captures what I intend to argue below: that institutions tend to respond to conditions in a particular socio-political environment by usually becoming more alike (DiMaggio \& Powell 1991:66). I am most interested in coercive mechanisms (laws, ideologies) such as those set by the state which lead to the institutionalization of similar rules in organisational structures (compare DiMaggio \& Powell 1991:68). Yet the influence of the other mechanisms cannot be dismissed: mimetic isomorphism is partly caused by the presence of individuals in churches who are also political beings; while the apparent lack of attention by seminaries to preparing clergy to instigate or manage racial and linguistic integration represents normative isomorphism. My emphasis on structure brings my work more in line with "new" historical institutionalists (who focus on structure) than with rational choice theorists (who emphasise individual action).

In my perception, the world system and the nation-state align with language practices at state and sub-state levels. Here I agree with sociological institutionalists who stress the importance of larger frames of reference. Nation-building and language outcomes can both be seen as examples of global and regional institutional isomorphism. From this perspective the similarities in language outcomes across former African colonies provide 
an example of institutional isomorphism operating at the national and global levels. At the national level institutional isomorphism is driven by the attempts of states to integrate nation-states to foster loyalty through policies and ideologies aimed at creating a common national identity.

Any consideration of local social change should be considered against the global system to see whether it was prompted by developments at that level. My analysis below will proceed against the backdrop of an eclectic world system perspective (without the hyphen). As such I will retain and synthesise - somewhat loosely - world-economy and world-polity norms into a implicit analytical framework. Some synthesis is possible due to a level of agreement between world-economy and world-polity theories. In worldeconomy theory an ideological system operates (Wallerstein 1990:38), which seems similar to the notion of global norms in world-polity (Meyer 1987; Boli 1980, 1987, 1993; Meyer, Boli, Thomas, \& Ramirez 1997). World-economy and world-polity theorists also seem to agree on the relevance of location in overall system. Both perspectives accord some significance to cultural hegemony, the role of the nation-state in nation-building, and the absence of a central actor in the world system.

Obviously I am not suggesting that structural similarities between world-polity and world-economy theories should paper over their differences. For example, world-polity theorists like Meyer and Boli argue strongly that global norms operate independently of the world-economy, and determine the legitimacy and structures of nation-states within a global polity. By contrast, Wallerstein considers a global ideas system to legitimate the world division of labour. For the latter world culture plays a secondary rather than a primary role "in the reproduction of contemporary world order", and vice versa, as Chase-Dunn (1989:88-104) observed.

So why insist on a synthesis? Principally because of the difficulty of separating world culture, which drives isomorphism, from the world-economy or from the world-polity. And like world-polity advocates, world-economy theorists do acknowledge that obvious isomorphisms have been produced to some extent within the world-system. For ChaseDunn the mechanisms are "cultural imperialism and the ideological hegemony of European religion, politics, economics, and science" (Chase-Dunn 1989:98). As a result consensual symbolic systems are emerging globally in the form of "certain underlying cultural themes", which are "at the least shared by national elites everywhere" (ChaseDunn 1989:98,100).

So my world system theory consists of a conceptual tool kit, taken from three perspectives on the world system. Globalization theory provides the notions of glocalization, and the inherent dialectical tension of heterogeneity and homogeneity. World-economy supplies the centrality of geographic stratification (i.e. core-periphery relations). World-polity contributes a central analytical concept in this study, namely institutionalism, particularly the concepts of institutional ecology and isomorphism. From this perspective, South Africa's nation-building project represents local attempts to 
address the twin paradoxical global pressures of increasing pressure for equality of opportunity for all (i.e. social equity), and insistence on recognition of cultural differences (see Rex 1986:120).

Page 626

Journal of World-Sistems Research

\section{METHODOLOGY AND SAMPLING PROCEDURE}

The empirical data for this study was collected as part of research conducted between 1995 and 1997. I was particularly interested in finding congregations with high levels of racial and high levels of linguistic diversity. The unit of analysis was congregations, a meso-level phenomenon, but various aspects of demography and diversity that affect congregations at the macro- and micro-levels were included. Although the research approach was qualitative, I attempted to gather a representative sample across the three denominations selected.

I lean towards a nomothetic perspective, wanting to explain similarities within different congregations by reference to the global structure. Yet this does not mean that idiographic elements are not present; particularly as I consider the 60 cases as a single case study in order to place them within a world system perspective.

The three major "English-speaking" Christian denominations which were finally included claim never to have followed segregationist policies, namely the Anglicans (Church of the Province of South Africa), Methodists (Methodist Church of Southern Africa), and Roman Catholics. The rationale for the inclusion of denominations in the survey were size (affiliation) and non-segregationist ideology, while individual congregations were selected primarily for being racially diverse. As Table 1 shows, these three denominations have a combined affiliation of 7,25 million people - about $26 \%$ of the total South African population, and $28 \%$ of all South African Christians (unless otherwise indicated, figures reflect the Human Science Research Council's 1993 Omnibus Survey). In addition a major Pentecostal-Charismatic grouping was also included as representing different theological and structural traditions, namely the International Federation (formerly "Fellowship") of Christian Churches.

\begin{tabular}{|c|c|c|c|}
\hline \multicolumn{4}{|c|}{ Table 1: Size of largest denominations represented in study, 1992 estimates } \\
\hline Denomination & Affiliation & Number of churches & Number of clergy \\
\hline Anglican & 2000000 & 1200 & $\begin{array}{l}12 \text { bishops } \\
1300 \text { priests }\end{array}$ \\
\hline Catholic & 2750000 & 875 parishes & $\begin{array}{l}32 \text { bishops } \\
1280 \text { priests }\end{array}$ \\
\hline Methodist & 2500000 & 6450 & 941 ministers \\
\hline IFCC\# & 400000 & 600 & 900 ministers \\
\hline \multicolumn{4}{|c|}{ Source: Froise 1992.} \\
\hline
\end{tabular}


In the Methodist, Anglican, and Catholic denominations, blacks and black languages proportionally outweigh other language and racial categories, comprising $12 \%$ of all Catholics, and 11\% of all Methodists (Zaaiman 1994). "Coloureds" make up the largest single grouping in the Anglican church, namely $26 \%$, as Table 4 shows. Together the Anglicans, Catholics, and Methodists have a combined membership of 7,25 million about $26 \%$ of the total South African population and $28 \%$ of all South African Christians (unless otherwise indicated, figures reflect the Human Science Research Council's 1993 Omnibus survey).

An initial small-scale pilot study was conducted between 1995 and 1996, involving 36 congregations. Addresses of suitable congregations were obtained by means of a snowball method. Three data-gathering methods were used, comprising: a postal survey of 24 congregations; workshops initially involving 36 congregations held in Pretoria (1996), Durban (1996), Cape Town (1995 and 1996) - followed by three in Cape Town (1996) which examined the historical process of racial incorporation in three Anglican congregations; and lastly telephone interviews with 23 clergy and a Methodist bishop. Not all congregations involved in the pilot study were included in the second phase.

In the final study 56 regional church officials (e.g. bishops or administrative secretaries) identified - on request - some 222 congregations in their areas which they believed contained "significant mixes of people from different race or language groups". This total is quite small, as the combined total of such congregations in the Anglican and Methodist churches make up less than $3 \%$ out of an estimated 7650 congregations. The final survey comprised a postal survey in 1997 of the 222 congregations and 12 telephone interviews. In the survey clergy were asked to complete a questionnaire with the assistance of at least 5 lay leaders, while in the telephone interviews a semi-structured schedule was used.

The survey yielded 60 valid cases out of 75 received, resulting in a final response rate of $34 \%$ when measured against the universe of 222 . Seven denominations were represented, i.e. the Church of the Province (CPSA), the Roman Catholic Church (RC), Methodist Church (MCSA), the (Pentecostal-oriented) International Federation of Christian Churches (IFCC) and one Independent, one Presbyterian, one Free Methodist Church. Of the 60 cases, 35\% (21) were Anglican congregations, 33\% (20) Catholic, 15\% (9) Methodist, while $10 \%$ (6) belonged to the IFCC. The 60 congregations represent 7 out of 27 Catholic diocese and archdiocese; 8 out of 12 Anglican diocese; and 3 out of 11 Methodist districts. The 60 congregations represent an estimated total of 18586 people, of whom the Charismatic-Pentecostal IFCC and Catholics make up the two single largest groups at $50.16 \%$ and $30.35 \%$ respectively.

The low response rate was due in part to incorrect information supplied by denominational officials, who did not always know what was happening in the churches under their supervision. While those churches which did not respond may differ from 
those that did, my impression - based on typologies developed in previous studies - is that the sample was fairly representative of types of integrating congregations. From experiences with workshops involving integrating congregations I assume that those who did not respond were not that well-integrated, felt that integration did not present a particular problem, or did not trust my provenance as attached to an Afrikaans - and so ostensibly politically conservative - university.

Are these congregations truly reflective of trends in South African society as a whole? In language terms yes, if evidence from research on university students, state organisations, education institutions, and transaction interactions in commercial settings are anything to go by. And not only representative of South Africa, but of language practices which ensconce a foreign language across Africa as a whole. So while the data-set is small, its robustness is improved by association with other studies who have shown similar trends in other domains and at other levels of analyses.

I now turn to a discussion of how race and language functioned in the history of the three major denominations in this study, based on recent research (Venter 1994, 1995, 1996, 1998). The data from the survey is presented below in a quantitative form, yet in essence was qualitative, and based on impressions of leadership. The 60 cases do provide broad enough evidence to comment on general patterns for integrating congregations, especially where supported by studies of related phenomena in society, e.g. language preference. I acknowledge, though, that further investigation at the micro-level is necessary to confirm my conclusions.

\section{LANGUAGE AND RACE IN THE MAJOR CHRISTIAN DENOMINATIONS}

My primary focus is on the three major English-speaking Christian denominations who claim never to have followed segregationist policies, namely the Anglicans, Methodists, and Roman Catholics (see Table 2). In addition a major Pentecostal-Charismatic grouping was also included as representing different theological and structural traditions, namely the International Federation (formerly "Fellowship") of Christian Churches. The rationale for the inclusion of three of the four major denominations were based on size (affiliation) and non-segregationist ideology, while individual congregations were selected primarily for being racially diverse.

Table 2: Affiliation as percentage of the total South African population, 1960-1993

\begin{tabular}{|lllll|} 
& 1960 & 1970 & 1980 & 1993 \\
\# Anglican & $8.78 \%$ & $7.87 \%$ & $6.48 \%$ & $5.98 \%$ \\
Methodist & $10.68 \%$ & $10.58 \%$ & $8.49 \%$ & $9.52 \%$ \\
Catholic & $6.73 \%$ & $8.71 \%$ & $9.47 \%$ & $10.18 \%$ \\
\hline
\end{tabular}


Source: HSRC Omnibus Survey 1993. Used by permission of the Sociology Departments of Huguenot

College and the University of Pretoria.

Note: \# Includes the Church of the Province of South Africa as well as the Church of England.

As far as language is concerned, more than 23 languages are spoken in South Africa. These can be subdivided into seven groupings (percentage of the total distribution of the eleven official languages in brackets), namely Nguni languages: Zulu (22\%), Xhosa $(17 \%)$, Ndebele (16\%), Swati (2.6\%); Sotho languages: North Sotho $(9.7 \%)$, South Sotho $(6.7 \%)$, Tswana $(8.6 \%)$; Tsonga $(4.4 \%)$; Venda $(2.2 \%)$; European languages and derivatives: Afrikaans (15\%), English (9\%), and small percentages of Dutch, German, Greek, Italian, Portuguese, French; Asian languages: Tamil, Hindi, Telegu, Gujerati, Urdu, Chinese; Other e.g. sacred languages such as Arabic, Sanskrit, and Hebrew (compare Desai 1994:26; Popenoe e.a. 1997:29).

No single language group has been captured by a particular Christian brand but, as Table 3 shows, various languages are distributed across the three major Christian denominations involved in the study. A similar distribution occurs across other denominations. The exception is Afrikaans-speakers, who tend to belong to either the Uniting or Dutch Reformed Churches.

Table 3: Language as percentage of denominational affiliation, 1993

\begin{tabular}{|c|c|c|c|c|c|c|c|c|}
\hline & Eng & $A f r$ & Xhosa & Zulu & Sotho & $\begin{array}{l}\text { Sha! } \\
\text { Tso }\end{array}$ & $\begin{array}{l}\text { Swal } \\
\text { Nde }\end{array}$ & $O / E$ \\
\hline Anglican & $39.1 \%$ & $13.5 \%$ & $15 \%$ & $14.3 \%$ & $0.8 \%$ & $1.5 \%$ & $0 \%$ & $.8 \%$ \\
\hline Catholic & $19.3 \%$ & $10.9 \%$ & $6.8 \%$ & $37 \%$ & $22.9 \%$ & $1 \%$ & $1 \%$ & $0.5 \%$ \\
\hline Methodist & $16.1 \%$ & $14.9 \%$ & $14.9 \%$ & $27.6 \%$ & $21.8 \%$ & $1.7 \%$ & $2.9 \%$ & $0 \%$ \\
\hline
\end{tabular}

Source: HSRC Omnibus Survey 1993. Used by permission of the Sociology Departments of Hugenote Kollege and the University of Pretoria.

Note: Eng=English, Afr=Afrikaans, Sha/Tso=Shangaan/Tsonga; Swa $/$ Nde=Swati/Ndebele; $\mathrm{O} / \mathrm{E}=\mathrm{Other}$ European; $\mathrm{O}=$ Other

Historically missionaries had a strong influence on language development, as they learnt - and standardised - indigenous languages. Yet from early on a division of labour emerged among missionaries who could speak indigenous languages, and other clergy who could not. For example, in the 1800 s few Catholic priests could speak indigenous languages, and so served mainly the white urban areas, where Mass was conducted in Latin and the sermon or instruction in English (Brain 1991:71). In this way language and race became interrelated. so that language differences corresponded to racial segregation. Even in the Catholic Church, which "recognised no colour bar from the earliest times, all Catholics sharing the same building and joining in the same worship", "difficulties of language and distance" led to segregated parishes in the Transvaal of the 1890s (Brain 1991:71). By contrast, the Catholic parishes of the Cape of the 1880s "included both 
European and coloured" (Brown 1960:204). But once the tribes across the Orange were thought of in 1840, the pattern of Catholic mission changed to segregated missions, as European civilisation was considered unlikely to dominate there (Brown 1960:204; see Oosthuizen 1968:15).

As a percentage of denominational affiliation (Table 4), blacks form clear majorities in the Catholic, Anglican, and Methodist Churches. Blacks make up almost $70 \%$ in both Catholic and Methodist Churches, but less than half of the Anglican church. White Anglicans have decreased from $12.49 \%$ in 1960 to $7.72 \%$ in 1993 according to HSRC data ${ }^{4}$. Coloureds form a significant minority in the Anglican church, a factor which reportedly affects church politics in regions such as the Northern and Western Cape where they form a majority.

Table 4: Race as percentage of denominational affiliation, 1993

\begin{tabular}{l|llll} 
& Black & Coloured & Asian & White \\
\hline Anglican & $46.62 \%$ & $26.32 \%$ & $1.5 \%$ & $25.56 \%$ \\
Catholic & $69.27 \%$ & $15.63 \%$ & $5.73 \%$ & $9.38 \%$ \\
Methodist & $69.54 \%$ & $14.37 \%$ & $0.57 \%$ & $15.52 \%$
\end{tabular}

Source: HSRC Omnibus Survey 1993. Used by permission of the Sociology Departments of Huguenot College and the University of Pretoria.

So despite the ideal of racially-mixed services expressed by most denominations in the 17 th to 19 th centuries in the first colonised region of South Africa (the present Western Cape), racially-integrated congregations are rare in South Africa today. This is in great part due to the political policy of residential and social segregation enforced by the apartheid regime between 1948 and 1990, a policy with antecedents in the colonial period. Some congregations put the ideal into practice until about 1872 .

Where incorporation of people of colour into the English-speaking churches occurred, it happened on the basis of their social position as subservient labourers to whites. So the master-servant relationship functioned to integrate these congregations, and continued to structure relations in the form of separated seating arrangements for different classes (read: races). Leadership remained the exclusive preserve of white male landowners. Superficial integration was often contradicted - or at best skewed - by the occasional turning away of people of colour, and by the overriding equation of white civilisation and culture with Christianity (compare Villa-Vicencio 1988:43,47,54; Maimela 1988:323; Goedhals 1989:108).

Over the last two decades of the 19th century, separate communion services and segregated services became the norm - with some exceptions. Eventually segregated congregations became the rule well into the 1980 s. In most white congregations a "three 
o'clock service" developed for black domestic workers. These euphem istically-termed "afternoon services" are held primarily for domestic workers in vernacular languages under the authority of a black clergy-person based in a nearby black "township" congregation.

While the English-speaking denominations technically remaine d racially-mixed in terms of having white and black clergy, the rate of racial integration into national church structures was very slow, as revealed by a comparison of church founding dates with the appointment of e.g. blacks to denominational positions. The Catholic church was founded in 1834, and the Anglican church in 1848. In the Anglican church only white bishops were appointed until 1953, and all had been born in England. The first black bishop (Alpheus Zulu) was appointed in 1960, and the first black archbishop (Desmond Tutu) in 1986 (Goedhals 1989:120,124; Cawood 1964:16,56; Hinchliff 1968:240). By 1980 only one diocesan and four suffragan (assistant) bishops were black. By 1988 nine out of 18 diocesan bishops and five suffragan bishops were black (Goedhals 1989:121; Pato 1989:172).

The Methodist church was established in South Africa in 1814, but the first black Methodist president (Seth Mokitimi) was only elected in 1963 (Gish 1985:74). In the whole history of the MCSA only seven black presidents had been appointed by 1988 (Gish 1985:4,69). The current Presiding Bishop (Mvume Dandala) is also black. Apart from most congregations, subregional (circuit) structures were also segregated. As a result, the Methodist Church of Southern Africa initiated a policy advocating integration of regional structures in 1976, and recently extended this policy downwards to integrate situations where two separate racially-segregated congregations were using the same church buildings at different times. A similar integrative dynamic is in operation in the Church of the Province of South Africa (Anglican).

In the light of the above, the most remarkable aspect about racially-mixed local congregations in South Africa is not that they do not exist, but that some exist at all. Surprisingly, some continued to exist through the dark years of apartheid, e.g. Catholic Cathedrals in Cape Town, Johannesburg, Pretoria, and Kimberley (Cawood 1964:10; Brain 1991:157), as well as ordinary congregations in e.g. Kalk Bay. Of particular interest are the deliberately integrated congregations which emerged in conscious defiance of the political system during the dark years of apartheid. These did not appear formally until 1962 in the form of North End Presbyterian Church, East London; and in 1968 in the Buitenkant St Methodist Church, Cape Town.

In the post-1990 era racially-mixed congregations have demonstrably been multiplying faster than before due in part to demographic changes in urban areas. Previously racially homogeneous urban Christian congregations now have to manage an increasingly diverse racial, linguistic, and cultural membership. As a result people are increasingly drawn into such multilingual settings alongside others previously classified as "other". An arbitrary breakdown shows clearly that the rate at which congregations are integrating is speeding 
up. Thirteen racially-integrated congregations emerged during 1974-1989, compared to the 24 that did between 1989-1997. In the 63 years from 1830 to 1899,7 congregations were racially integrated, compared to the 7 that became mixed over the next 48 years (1900-1948). During the next 24 years (1949-73) the integration-rate slowed down, with only 4 achieving this status. But the inverse happened over the subsequent 23 year period (1974-97), with 37 congregations becoming integrated.

Next I profile the 60 cases as a basis for my discussion in the penultimate section. Without exception, these are all examples of either congregations which have always been integrated, or formerly white congregations which have recently become integrated. What the situation is in black multilingual congregations still remains to be investigated. What little I know about them suggests that due to the multilingual facility of black South Africans, congregations in multilingual settings will, at least, have thoroughly bilingual services. The exceptions would probably occur in highly homogenous settings.

\section{DESCRIPTION OF CASES}

Of the 60 cases, 35\% (21) were Anglican congregations, 33\% (20) Roman Catholic, $15 \%$ (9) Methodist, while $10 \%(6)$ belonged to the International Fellowship of Christian Churches (IFCC).

Language was seen as the most prominent marker of diversity, was perc eived as the most problematic, and was cited in a multiple option response by leaders of $39.3 \%$ ( 33 of 60 ) of churches as the form of diversity which at present most influence their congregation's structures. Most respondents perceived their congregations to be in neighbourhoods that were substantially linguistically diverse. In general, $75.9 \%$ of respondents (44 of 60 cases) reported that two or more language groups occurred in the neighbourhoods around their congregation's buildings - including $27(46.6 \%)$ which were in neighbourhoods where three or more languages are spoken. In other words, only $24.1 \%$ (14) described their neighbourhoods as linguistically homogenous.

Responding congregations were asked to indicate the approximate percentage of first language speakers in their respective congregations. Ten of South Africa's eleven official languages were distributed over the 59 valid responses, while the number of first languages of congregants in a particular congregation ranged from two to 11 languages, excluding foreign languages. The presence of up to four first languages in a congregation was fairly common. Forty-five congregations (76.3\%) contained $1-4$ first languages; 12 $(20.3 \%)$ between 5 to 8 ; and two $(3,4 \%)$ had 9 to 12 first languages. A similar number of congregations had five ( 5 or $8.5 \%$ ) languages than had six first language-speakers ( 4 or $6.8 \%)$. 
Despite the English-speaking label of the denominations to which these churches belong, in a quarter (16 cases) English first-language speakers made up 33\% or less of the total membership, as Table 5 illustrates. In 11 congregations (19.7\% of 59) surveyed, the number of people who spoke English as first language made up less than $20 \%$ of the total. Three churches (3.6\%) reported that no English was spoken by members of their congregations. At the other end of the scale English first-language speakers formed a majority ( $50 \%$ or more of all members) in 40 out of 60 congregations, which includes a two-thirds majority (more than 66\%) in 29 cases (or 47.5\%). In all, English first-language speakers were distributed across 55 congregations.

\begin{tabular}{|c|c|c|}
\hline $\begin{array}{l}\text { \%of English first language } \\
\text { speakers }\end{array}$ & No. of Cases & Percentage \\
\hline None & 3 & $3.6 \%$ \\
\hline $1-33 \%$ & 13 & $22 \%$ \\
\hline $34-66 \%$ & 17 & $28.8 \%$ \\
\hline $67-100 \%$ & 28 & $47.5 \%$ \\
\hline Source: Own data, 1997. & & \\
\hline
\end{tabular}

Afrikaans was spoken by more than $50 \%$ of the congregation in 8 out of 59 churches (i.e. $14.8 \%)$. Altogether $18(35.9 \%)$ reported that $25 \%$ and more of their congregation was Afrikaans-speaking. In $12(20 \%)$ no Afrikaans-speakers were reportedly present. In 54\% of all churches surveyed Afrikaans formed the first language of $8 \%$ or less of the total membership. Afrikaans first-language speakers were spread over 46 congre gations. European first-language speakers (other than English) were distributed over 19 cases, and Asian first-language speakers over eight. In terms of African languages, Zulu was spread over 23 congregations, Xhosa over 18, Sotho over 15, Tsonga over 6, Swazi over 5 , Venda over 2, Shangaan over 4, Pedi over 4, Tswana over 3. Other African first-language speakers were distributed over 17 congregations (29\%).

Congregational integration was measured along two dimensions, namely race and language.

The extent of racial integration was measured in terms of a racial-integration index, which indicated how representative the leadership, home groups, and outreach programmes of congregations were. I assumed that the level of integration was interrelated to the level of diversity, as would racial integration relate to language integration. Table 6 reviews the extent to which racial integration has occurred. The index represents a ranking according to the total score that could be obtained when scores from three categories were added: mixed, some mix, or representative of the racial diversity of congregants. Through this multidimensional method $54.9 \%$ ( 28 of 51 cases) could be said to be substantially integrated, with $39.2 \%$ (20 cases) somewhat integrated, and $5.9 \%$ (or 3 cases) poorly integrated. 


\begin{tabular}{|c|c|c|c|c|}
\hline \multicolumn{5}{|c|}{ Table 6: Racial integration index } \\
\hline Level & Overall \% & Leadership & Programmes & Home groups \\
\hline Poorly integrated & $5.9 \%$ & $17.5 \%$ & $15.4 \%$ & $15.1 \%$ \\
\hline $\begin{array}{l}\text { Somewhat } \\
\text { integrated }\end{array}$ & $39.2 \%$ & $40.4 \%$ & $44.2 \%$ & $47.2 \%$ \\
\hline Well integrated & $54.9 \%$ & $42.1 \%$ & $40.4 \%$ & $37.7 \%$ \\
\hline$N=$ & $51 *$ & $57(a)$ & $52 \#$ & $53 \$$ \\
\hline $\begin{array}{l}\text { Source: Own data, } 1 \\
\text { Notes: } \\
* 5 \text { invalid response } \\
\text { (a) } 1 \text { invalid respons } \\
\# 2 \text { invalid response } \\
\$ 2 \text { invalid response }\end{array}$ & $\begin{array}{l}997 . \\
4 \text { no respon } \\
, 2 \text { no respo } \\
, 6 \text { no respo } \\
5 \text { no respo }\end{array}$ & & & \\
\hline
\end{tabular}

The linguistic-diversity index, as Table 7 indicates, comprised 5 categories: number of languages spoken in sermons, hymns, liturgy, praying, and readings. The level of linguistic integration is represented in terms of whether or not their services reflect the number of languages in the congregation, i.e. whether they are essentially mono-, bi-, or multilingual.

Six congregations placed in the "well-integrated" category, compared to 22 in the "somewhat" and 25 in the "poorly" integrated categories. No single identifiable variable emerged that could explain similarities among the six congregations that were linguistically well-integrated, nor the differences between these and the 25 with poor linguistic integration. There seems to be some inverse correlation between number of first languages spoken and level of linguistic integration. A high number of first languages (ten or more) appears to be associated with somewhat integrated churches. Where relatively fewer languages are present ( 2 to 6 ), higher rates of language integration is reported. Higher levels of linguistic diversity in neighbourhoods appears not to be associated with higher levels of linguistic diversity in congregations. Neighbourhoods with high levels of linguistic diversity seem mostly associated with congregations with medium levels of diversity.

Table 7: Language integration index: number of languages in congregation and number used in services $(\mathbf{N}=\mathbf{5 3})^{*}$

\begin{tabular}{|l|llll|}
$\begin{array}{l}\text { Level of integration } \\
\text { (index) }\end{array}$ & $N$ & $\begin{array}{l}\text { Number of languages in } \\
\text { congregation \# }\end{array}$ & $\begin{array}{l}\text { Number of languages used } \\
\text { in service }\end{array}$ & $\begin{array}{l}\text { Total as \% of } \\
\text { responses }\end{array}$ \\
$\begin{array}{l}\text { Poorly integrated } \\
\text { Somewhat } \\
\text { integrated }\end{array}$ & 25 & Three or more (multilingual) & One (monolingual) & $47.2 \%$ \\
& 9 & Two (bilingual) & One (monolingual) & $17.0 \%$ \\
Well integrated & 4 & Twree or more (multilingual) & Two (bilingual) & $24.5 \%$ \\
\hline
\end{tabular}




\begin{tabular}{|c|c|c|}
\hline 2 Three or more (multilingual) & $\begin{array}{l}\text { Three or more } \\
\text { (multilingual) }\end{array}$ & $3.8 \%$ \\
\hline $\begin{array}{l}\text { Source: Own Data, } 1997 . \\
\text { Note: \# Number of first languages spoken by congregants. } \\
\text { * } 6 \text { invalid responses, } 1 \text { no response. }\end{array}$ & & \\
\hline
\end{tabular}

What is somewhat disguised by Table 7 is that monolingual services - usually English are the norm in multilingual congregations regardless of the size of other language groups. One language is used in the services of $64.2 \%$ congregations ( 34 of 54 cases). This is the more remarkable as in 46 congregations ( $76.7 \%$ of 60 cases) three or more first languages occur. In $32 \%$ of responding congregations two languages are used (17), and in only $3.8 \%$ (2) are three or more used. Given the presence of more than one firstlanguage group in all congregations polled, bilingual services would have been the expected option, at the least. When the number of languages used in the service is broken down into a more detailed picture, $74.1 \%$ of responding congregations ( 40 cases) are seen to have had monolingual preaching only. By comparison about a quarter had bilingual sermons (13 cases or $24.1 \%$ ) and only one (1.9\%) multilingual sermons.

A comparison of the indices clearly show the relatively well-integrated racial nature of the congregations compared to the poorer linguistic integration. Other major trends can be summarised as follows:

a. most congregations exhibit some form of linguistic diversity, but with low levels of multilingualism;

b. most congregations prefer monolingual sermons;

c. linguistic diversity tends to be expressed in the form of bilingualism;

d. English predominates as language of choice in multilingual settings;

e. integrating congregations are associated with neighbourhoods with high levels of diversity

In the next section I attempt to provide a interpretative framework for these tendencies which gives attention to structure and agency, while examining the interplay of micro-, meso-, and macro-factors.

\section{DISCUSSION}

The discussion in this section remains at the level of informed speculation, and applies only to general trends among integrating congregations. The same factors are also present in congregations whose make-up is far more representative of their congregants, but then occur with a positive emphasis. While I would argue that the evidence points to a 
surprising lack of linguistic and cultural accommodation in integrating congregations, there are exceptions.

There are several critical elements which constrain linguistic diversity in South Africa; some which can be mentioned briefly, others which require more detailed analysis. The former include the enforced use of Afrikaans under Afrikaner nationalism and the negative reaction to that by the majority of South Africans, which effectively delegitimated that language. Also, native English-speakers provide another example of inhibiting factors, as they have the biggest impact on language preference in multilingual settings. In the case of integrating congregations, this means white congregants, or immigrants who may technically be multilingual but not in any South African language. And, reluctance on the part of congregational leadership (clergy, lay leaders) inhibits the operation of multilingual or multicultural identities.

In addition there are two major factors which require more detailed analysis.

The first comprises the constraints posed by institutional setting on the ability of linguistic or ethnic identities to advance their own interests in congregations. Here organisational culture is of particular interest, while the vector formed by class, language and religion with the integrative dynamic of the congregations also acts as brake.

Apparently institutional culture continues to favour the unofficial national language English, and in a few cases the old official language, Afrikaans in the setting of "Englishspeaking" Christian denominations. The same ambiguity which marks official policies (good intentions contradicted in practice) occurs here. Linguistic diversity is now reflected in most liturgical publications (Prayer Book of the CPSA) and hymnals, but evidence shows that this is not necessarily translated into congregational life. It is hard not to conclude that South African mainline congregations are "still dominated by European Christian forms" (Ramphele 1989:179). As social institutions, denominations are carriers of the social, cultural, economic, and political forces in society (see VillaVicencio 1988:42). And so congregations also contain the values of European culture embedded in the language, structures and processes of their denominations (Ramphele 1989:179; see Cochrane 1987:26; Saayman 1994:12; Bill 1994:168).

The evidence also suggests that the intersection of language and religion in an integrative setting favours middle class aspirations and formation. A lot of ink has been spilled recently about the emergence of a black middle class, for whom English fits class aspirations. Most mixed congregations seem to follow the ideal set by black political elite, namely the primacy of English, and so offer a natural home to this group who are easily integrated into existing leadership structures without affecting the internal 
functioning of congregations. Black languages and customs are seldom allowed any space to function, with the exception of hymns translated into Bantu languages. In this way current integration in practice reinforces class divisions, structures of exclusion, and internal colonisation with respect to indigenous languages and cultures. Lower income blacks are integrated in terms of their existing class position.

As can be seen from the next major constraint discussed below, these practices stretch back to colonial times, and apparently have been systemically reproduced to the present day. Under the impact of the Christian missions indigenous societies divided between those who used tradition to oppose domination, those who accepted the cultural dominance of settlers, and those who opposed political exclusion and economic exploitation in Christian terms. The so-called English-speaking churches incorporated indigenous peoples into a European-derived belief system, in which the economic and political structures of the settlers were replicated.

In these integrating congregations blacks, as then, who are allowed into leadership are fully acculturated and occupy the same class positions as their white peers. On the other hand blacks are utilising religious institutions to gain access to economic resources through assimilating their offspring. Meanwhile the marginalised segments of the population, in trying to emulate the status language of the elite, are arguably losing their ability to express themselves in indigenous languages, without emerging above inadequate standards of English. Prah has argued persuasively that this inability to conceptualise in the mother tongue adds to the inability of Africa to produce scientists of note.

The second major constraint on language preference in integrating congregations is posed by a language ideology which operates in South African society, but also across Africa, and is linked to features of the world system. In fact, I would argue that a language ideology, in the sense of attitudes towards languages, has been in operation in this country for a very long time. It structures languages (and so intergroup relations) in a status hierarchy in relation to one another, and deems that English is the only language fit for interstate, substate, and intergroup communication.

Such a language ideology is implicitly traced in other studies which examine the language attitudes of South Africans. The study of individual language preferences have often focused on universities, e.g. Vivian De Klerk's 1996 study of Rhodes students and Kwesi Prah's 1993 study of six Southern African universities; including the historically black Universities of the Transkei and of the Western Cape. Studies of the general public have been conducted by the Human Sciences Research Council (e.g. Schuring 1979), the South African Broadcasting Corporation (see Gough 1996:55), and the Institute for a Democratic South Africa (unpublished 1997).

The origin of the ideology lies in the Anglicisation policies of the colonial and Union periods, but can also be located in global politico-economic factors which favour the 
domination of particularly English and North American cultural forms. The increasing dominance of English in South Africa can also be explained by the indebtedness of major institutions here to the United Kingdom - and the USA, as is the case with other Commonwealth nations. As a result, structures and organisational cultures discriminate against other language and cultural groups, ensuring that European-derived languages dominate (cf. Castles 1992). I do not argue that world ideology directly affects local congregations, but rather that global norms affect the state-building project in terms of the direction taken by language practice and ideology, and that this is reflected in the dynamics of congregations, as it is in the education system. In this way language ideology locally is tied to the global language ideology.

In addition, a small but significant proportion of past and recent leaders of the liberation movement were educated in English or in British educational institutions. The roots of a pro-English bias in the black resistance movement originated in the vector formed by state, education, and religious institutions in the pre-apartheid era. Before 1948 English mission schools produced English-speaking black intellectuals, including the founders of the African National Congress (in its early guise as the African Native National Congress). Examples include Sol T Plaatje, Walter Rubusana, Pixley ka Isaka Seme, John L Dube, Sam Makgothi, and Saul Msane (Maake 1994:114). The founders of the Pan Africanist Congress were also schooled by the missions, "such as Robert Mangaliso Sobukwe, Anton Mziwakhe Lembede, Zaphania Mothopeng". These men were described by H F Verwoerd as "'Black Englishmen"' (Maake 1994:114).

When the dominance of English is superimposed onto the hierarchical geographical ordering of the world-economy it becomes clear that the language of two former core states - the former hegemon, Britain, and the recently dominant USA - is now the "supercentral" language (De Swaan 1989, 1994). English has achieved pre-eminent status as global language (Crystal 1997), as a result of the expansion of cultural hegemony through economic means, and of Western education systems as part of the globalization of development. As the world-economy is dialectically linked to cultural change, cultural hegemony accompanied the expansion of the world capitalist system. The preference for English is supported through the example of the state and various elites, but also through the common understanding that English is the language of status and commerce.

This is not to deny that reciprocal influences from the periphery do affect the core, nor that alternative language options do not figure in world culture, setting up contradictory trends. On the one hand the world-capitalist system often requires trade to be conducted in the supracentral language of the dominant core state, and aid agreements to be concluded in favour of the same language, namely English. But on the other hand the norms circulating within the world-polity require that nation-states acknowledge and protect constitutionally the diversity of its peoples. Thus two ideologies have been established within the world system which in linguistic terms simultaneously promote monolingualism and multilingualism, homogeneity and he terogeneity, as well as hybridity. 
In the politics of difference, a pertinent question is which language/s will dominate public and private institutions. Across many institutions languages are in competition, and perhaps only the economically powerful will survive in the public domain in South Africa. English has achieved a renewed status as the unofficial official language, despite all the good policy intentions. English is increasingly advanced by some politicians as the dominant language for use in most major institutions (e.g. education, business, government).

\section{Factors which function to enhance linguistic diversity}

The rare cases where multilingual interaction occurred is often associated with sympathetic leadership, such as a sympathetic clergy person. The constraints of institutional culture are only overcome where the critical mass of mother-tongue congregants are so large that another language cannot be avoided. Cases were black congregants insist on cultural or linguistic inclusion are very rare.

Page 643

Journal of World-Systems Research

\section{CONCLUDING THEORETICAL REMARKS:}

\section{Analysing linguistic and racial integration through attention to interactions between and within meso-and macro-levels}

In South Africa the status and role of languages in meso-level interactions are now embedded in a language ideology, supported by the informal language policies embedded in the organizational culture of religious institutions which are labelled "Englishspeaking". Such a language ideology functions to dictate where and when a particular language is appropriate, and to enforce monolingualism. Congregations where the majority of members are not English-speaking, yet this is the language preferred, illustrate the point. There seems to be some consensus that the public realm is unsuitable for any language other than English, while the room for indigenous languages seems to be contracting. Obviously none of the above examples are purely about language, nor as straightforward as I represent them.

Elements of structure and agency interact to dampen linguistic and cultural diversity in many integrating congregations. At the macro-structural level language ideology, class formation, institutional and congregational setting, and changing demographics all play a role; as do the congregants as actors and the clergy as gatekeepers at the micro-agency level. Meso-level factors include the size of the congregation, the ratio of language groups in relation to one another, geographic location (rural-urban), and the policies of the denomination. For example, majority indigenous languages (macro-factor) only emerge in large congregations (meso-factor); in small congregations (meso-factor) congregants opt (micro-agency) for English (macro-factor).

As rational agents congregants, denomination al leaders, clergy, lay leadership all consciously or subconsciously bring the contestations between groups into congregations 
with them, while choosing to represent themselves in a particular way. Yet such microlevel actions are also constrained by other actors in the meso-level setting, such as the cultural ideology at work in society at the macro-level and in the organization at mesolevel. In other words, while the purpose of the setting is to reinforce a particular social identity, that of Christian believer, church members also bring multiple identities into that setting, some which are repressed and others which are selected. Language symbolises which identity is deemed more relevant to that setting, and demonstrates the perceived status between different language groups.

In most integrating congregations an awareness of the need for multiculturalism is evident in the recent inclusion of samples of linguistic diversity in hymns and readings. While these acknowledgements of diversity are symbolically necessary, regrettably their limited scale of usage means that they will have little effect on existing class or status relations between congregants. Should such practices continue, the national policy of multilingualism will not be advanced, but instead the marginal status of black languages will be confirmed and confined to "minority" rankings. This multilingualism merely enhances the status of English, stigmatises other languages, and leads to a form of linguicism - a form of discrimination against minority groups based on language preference.

At the same time competing loyalties to language and ethnic group are undercut by contending religious and national identities. While elsewhere language and religion have contributed powerfully to ethnic identity formation, this has not happened in South Africa, as more missionaries were at work here during the colonial era than elsewhere on the continent. Ethnic groups were broken up among the denominations, so that religion and ethnicity were different sources of identity with little overlap between them.

Membership in mainstream and Pentecostal Christianity tends to neutralise the attraction of local ethnic identities by offering global alternative identities, of being Catholic, etc. Anecdotal and personal experience suggests that believers tend to place loyalty to the Christian identities above other identities.

The same applies to racial identity: in accordance with the dominant non-racial ideology, racial identities are downplayed by denominational and congregational leaders (in line with similar sentiments in the social sciences here and abroad). Yet race demonstrably continues to affect the structures of religious organisations and the interactions within them. This is illustrated by the existence of a separate black caucus in some denominations (Anglicans, Methodists); the apparent need by church officials to (reclaim a history of racial integration (e.g. Catholics); election of denominational church leaders from certain racial backgrounds (Methodists); the exclusion of white clergy from certain regions (e.g. the Uniting Reformed Church, Anglicans); and a general reluctance from those formerly known as blacks and whites, as well as blacks and coloureds, to unite in regional or local congregational structures. 
Some congregations have little racial integration of leadership structures, but generally speaking racial integration is more noticeably present than is cultural or linguistic integration. In line with the anti-apartheid position of the churches, many actively espouse non-racialism in the sense of playing down the salience of race as category. In some denominations (Anglican) clergy are no longer required to report me mbership in terms of race. However this does not mean that awareness of race has diminished, or that racial integration has taken place. In some cases relations between black and white, or black and coloured are still strained. In the opinion of a clergy person the Black Consultative Forum in the Anglican church was unhappy with the disproportionately large number of white bishops. Another clergy person felt that the bishop in his diocese reportedly wanted to be "the first one who had no white clergy".

But the increasing domination of class values does not move churches away from race as an issue, for it is European upper and middle class interests which now dominate local congregational structures. These configurations of power enforce white standards of living (e.g. dress codes, even within black congregations), and deny other races access to leadership (see Ramphele 1989:187). Class structures in South Africa coincide with race in an 'internal hegemony', a tempered domination of power and privilege in which race no longer appears as the primary criterion. This structure was revealed in past attempts to de-racialise (church) systems without loss of [white] power, an exercise based on the recognition that dismantling privilege based on race must result in the collapse of (most ?) social infrastructures (Villa-Vicencio 1988:83,84).

\section{Analysing integration in terms of institutional change}

Institutional isomorphism can explain the tendency in integrating congregations to use English, by referring to the embeddedness of religious organisation in ever widening concentric contexts of national and global institutions, particularly polity and economy. The expansion of the world system in polity and economic terms is historically associated with the spread of colonialism, a process which led to the diffusion of state forms and instruments of state control and legitimation, namely education and, more ambivalently, Christianity as a world religion. Both mission education and imperialism established a cultural hegemony in British colonies which ascribed to English a higher status than to indigenous languages. Local elites were drawn into these institutions and in this way a language ideology was institutionalized and reproduced.

The difficulties that congregations have in integrating linguistic and cultural diversity demonstrate how problematic it is to replace one set of values and associated norms and roles with another in a context of coercive isomorphism formed by state and denominational policies. The result is the incomplete institutionalisation of non-racialism and multiculturalism. Following Moberg (1962:19-20), patterns of integration in congregations express institutionalised behaviour trends within a state-recognised institutionalized voluntary associational organisation. In this approach I analyse congregations as organisations in which several institutions (religion, gender, leadership) 
intersect. A congregation and the denomination to which it belongs represent different aspects of the same religious institution. Institutional change within both are brought about by extra-institutional mechanisms (values and norms in the institutional environment, e.g. nonracialism, nation-building) or intra-institutional mechanisms (e.g. through antagonistic actors who oppose one another in the same institution (compare Koelble 1995:235).

Within such an environment other institutions conform to various degrees, i.e. become isomorphic. In congregations that resist full linguistic and cultural integration, organisational inertia takes the form of loose coupling - that is, racial integration of leadership structures is the price paid in order not to deal with language or other aspects of culture. Notions of multiculturalism are not regarded as essential to organisational survival. Hypothetically, conformity to external policies depends on the extent to which intra-institutional support exists for the values which they represent. Congregations which initiated integration before the formation of the post-apartheid state were arguably more influenced at an extra-institutional level by the relations of its leaders to global organisations like the WCC. Yet, given the policies of the present state, it would become increasingly difficult for institutions dependent on state recognition to resist some measure of implicit conformity to these norms of behaviour. Hence institutional isomorphism is likely to develop more rapidly under the present state.

Page 647 Joumal of World-Systems Research

Integration in congregations can be viewed in terms of a dialectic cycle through which institutional change occurs in a local organisation. Only if values are institutionalised will they be successful; they will only be institutionalised if they are broadly accepted. Institutionalisation implies acceptance of ideas (values and norms), and their implementation in roles and behaviour. On this basis I would argue that congregations which are racially integrated only (along with those that are not integrated at all in contexts which would allow this) present instances of the partial institutionalisation of multiculturalism in contrast to the more complete implementation of nonracialism and nation-building. Racial equality has been institutionalised to the extent that it has penetrated the consciousness of individual congregants (other races should be equally included) and has been accommodated in the creation of formal roles (black lay leaders). Yet the norms that determine the status and roles that languages may play (English should dominate) remain unaffected. As a result indigenous languages are not included, and those congregants or clergy who would support their incorporation are rendered ineffective by the attitudes of both English-speakers and the other language groups, which accept the status quo.

Extra-institutional values - such as multiculturalism - are incorporated and unevenly distributed across the structures of the denomination. Among synodical representatives positive multicultural values are most clearly institutionalised as evidenced by policy and in the use of e.g. different languages in the Anglican prayer-book, but without affecting the norms governing the congregation. At the congregational level there may even be an obvious acknowledgement of the different value-set contained in denominational and 
state policy, but this has not as yet ousted the dominant cultural ideology. While there is little disagreement about the usefulness of allowing other races to be integrated, the roles and status associated with language and culture remain unaffected.

Extra-institutional values articulate with the cultural norms of the world system, namely equality and progress (Beyer 1994:23), and feed into the continuous need in the capitalist system for economic expansion. Equality, in the form of a globalized norm of liberal democracy, enables the removal of ethnic and racial barriers which could hinder the creation of new markets, a process undergirded by the diffusion of English as a global language through tertiary education and financial aids programmes. The globalization of liberal values supported the establishment of various charters of human rights, including the Freedom Charter, the present South African constitution, and the ideologies of nonracialism and multiculturalism. These values are expressed in state policies and legislation. Paradoxically, the world system also incorporates norms which establish a single global division of labour between core and peripheral states.

Global factors can explain the preference for English indirectly, as supported through the example of the state and various elites, and through the common understanding that English is the language of status and commerce. Anecdotal evidence points to an understanding in certain black circles that the state's multilingual policy is merely an ideological mechanism for the devaluation of Afrikaans and other minority languages (like Venda). This view, for instance, was aired by black clergy at a recent workshop for a denomination not included in this study.

Generally speaking, both whites and blacks in integrating congregations dominated by English accept the status quo. For speakers of minority African languages, English represents a neutral alternative to the linguicism expressed by major language speakers such as Zulu or Xhosa. For whites, the use of English maintains the dominance of European cultural values while appearing to conform to nonracialism; while for blacks it confers entry into a higher status and symbolizes the upward aspirations modelled by the new elite.

Page 649 Journal of World-Systems Research

\section{References}

Beyer, P 1994. Religion and globalization. London: Sage.

Bill, J-F 1994. The witness of the Presbyterian Churches in South Africa. International Review of Mission vol. lxxxiii No. 328: 167-172.

Boli-Bennett, J 1980. Global integration and the universal increase of state dominance, 1910-1970. In Bergesen, A (ed) Studies of the modern world system. New York: Academic Press, pp. 77-108. 
Boli, J 1987. World polity sources of expanding state authority and organisation. In Thomas, G M; Meyer, J W; Ramirez, Francisco, O \& Boli, J Institutional Structure: Constituting State, Society, and the Individual. Newbury Park: Sage, pp. 71-91.

Boli, J 1993. Sovereignty from a World Polity Perspective. Revised version of a paper presented at the annual meetings of the American Sociological Association, Miami, August 1993.

Brain, J B 1991. The Catholic Church in the Transvaal. Johannesburg: Missionary Oblates of Mary Immaculate.

Brown, W E 1960. The Catholic Church in South Africa. London: Burns \& Oates. Edited by $M$ Derrick.

Castles, S 1992. The Australian model of immigration and multiculturalism: is it applicable to Europe. International Migration Review 26: 549-67.

Cawood, L 1964. The churches and race relations in South Africa. Johannesburg: S A Institute of Race Relations.

Chase-Dunn, C 1989. Global formation: structures of the world-economy. Cambridge, MA: Blackwell.

Cochrane, J R 1987. Servants of power. The role of the English-speaking churches 19031930. Johannesburg: Ravan Press.

Cook, K S \& Levi, M (eds) 1990. The limits of rationality. Chicago: University of Chicago Press.

Crystal, D 1997. English as a global language. Cambridge: Cambridge University Press.

Davis, J H \& White, W W 1980. Racial transition in the church. Nashville: Abingdon Press.

De Gruchy, J W 1986. The church struggle in South Africa. Grand Rapids MI: Eerdmans. (2nd edition 1986, published jointly with David Philip, Cape Town).

De Klerk, V 1996. Use of and Attitudes to English in a Multilingual University. English World-Wide 17, 1:111-127.

Desai, Z 1994. Praat or speak but don't thetha: on language rights in South Africa. In Barton, D (ed) Sustaining local literacies. Clevedon, England: Multilingual Matters Ltd, pp. 19-29.

De Swaan, A 1989. Notes on the emerging global language system: Regional, National and Supranational. Unpublished paper. 
DiMaggio, P J and Powell, W W 1991. The Iron Cage revisited: institutinoal isomorphism and collective rationality in organizational fields. In Powell, W W and DiMaggio, P J (eds) The new institutionalism in organizational analysis. Chicago: University of Chicago Press, pp. 63-82.

Finnemore, M 1996. Norms, culture, and world politics: insights from sociology's institutionalism. International Organization 50 (2): 325-47.

Froise, M (ed) 1992. South African Christian Handbook 1993/94. Johannesburg: Christian Info.

Gish, S D 1985. The Methodist Church and Apartheid in South Africa. Paper submitted to the Departments of History and Literature of Religions. Evanston Ill: Northwestern University.

Goedhals, M 1989. From paternalism to partnership? The Church of the Province of South Africa and Mission 1848-1988. In England, F \& Paterson, T (eds) Bounty in bondage. Johannesburg: Ravan Press, 104-129.

Goke-Pariola, A 1993. The role of language in the struggle for power and legitimacy in Africa. Lewiston: Edwin Mellen. African studies, v. 31.

Gough, D 1996. Black English in South Africa. In De Klerk, V (ed) 1996b. Focus on South Africa. Amsterdam: John Benjamins.

Granovetter, M \& Swedberg, R (eds) 1992. The sociology of economic life. Boulder: Westview Press.

Hall, P A \& Taylor, R C R 1996. Political science and the three new institutionalisms. Political Studies 44: 936-957.

Hinchliff, P B 1968. The church in South Africa. London: SPCK.

Hirsch, P M 1997. Sociological theory without social structure: neoinstitutional theory meets brave new world. Review essay. American Journal of Sociology 102: 1702-1723.

Kaschula, R \& Anthonissen, C 1995. Communicating across cultures in South Africa. Johannesburg: Wits.

Koelble, T A 1995. The new institutionalism in political science and sociology. Review article. Comparative Politics 27: 231-243.

Kritzinger, J J 1995. The religious field. In Webb, V (ed) Language in South Africa: an input into language planning for a post-apartheid South Africa. The LiCCA (SA) Report. Pretoria: LiCCA, pp. 357-366. 
Langtag 1996. Towards a national language plan for South Africa-final report of the language task group (Langtag). Pretoria: Government Printer.

Lowndes, V 1996. Varieties of new institutionalism: a critical appraisal. Public Administration 74: 181-197.

Maake, N P 1994. Dismantling the Tower of Babel: in search of a new language policy for a post-Apartheid South Africa. In Fardon, R \& Furniss, G (eds) 1994. African languages, developments and the state. London: Routledge, pp. 111-121.

Maimela, S 1988. Doing theology in South Africa after the Kairos document. In Mouton, J, Van Aarde, A G \& Vorster, W S (eds) Paradigms and progress in theology. HSRC Studies in research methodology. Human Sciences Research Council, pp. 321 -334.

Massie, R K 1993. Local churches in the new South Africa. Journal of Theology for Southern Africa 85, 19-28.

Meyer, J W 1987. The world-polity and the authority of the nation-state. In Thomas, G M; Meyer, J W; Ramirez, Francisco, O \& Boli, J Institutional Structure: Constituting State, Society, and the Individual. Newbury Park: Sage, pp. 41-70.

Meyer, J W; Boli, J; Thomas, G M; Ramirez, F O 1997. World Society and the NationState. American Journal of Sociology 103 1:144-181.

Oosthuizen, G C 1968. Post-Christianity in Africa. A theological and anthropological study. London: C Hurst and Co.

Pato, L 1989. Becoming an African church. In England, F \& Paterson, T (eds) Bounty in bondage. Johannesburg: Ravan Press, pp. 159-176.

Popenoe, D; Cunningham, P; \& Boult, B 1997. Sociology: first South African edition. Prentice Hall.

Prah, K K 1993. Mother tongue for scientific and technological development in Africa. Bonn: Deutsche Stiftung fur internationale Entwicklung.

Ramphele, M 1989. On being Anglican: the pain and the privilege. In England, F \& Paterson, T (eds) Bounty in bondage. Johannesburg: Ravan Press, pp. 177-190.

Rex, J 1986. Race and ethnicity. Milton Keynes: Open University Press.

Saayman, W 1994. Christian mission in South Africa: a historical reflection. International Review of Mission Ixxxiii, 328: 11-20.

Schuring, G K 1979. A multilingual society - English and Afrikaans amongst blacks in the RSA. Pretoria: HSRC. 
Sjostrand, S-E (ed) 1993. Institutional change: theory and empirical findings. Armonk, NY: Sharpe.

Thomas, G M \& Meyer, J W 1984. The Expansion of the State. Anmual Review of Sociology 10: 461-482.

Thomas, G M; Meyer, J W; Ramirez, Francisco, O \& Boli, J 1987. Institutional Structure: Constituting State, Society, and the Individual. Newbury Park: Sage.

Venter, D 1994. The formation and functioning of racially-mixed congregations. Unpublished PhD-dissertation, Stellenbosch: University of Stellenbosch.

Venter, D 1995. Mending the multi-coloured coat of a rainbow nation: cultural accommodation in ethnically-mixed urban congregations. Missionalia 23 (3): 312-338.

Venter, D 1996. It may be art, but is it culture? The ANC's conceptions of culture and orientation towards ethnicity in the 1994 RDP booklet. Politikon 23 (2): 4-21.

Venter, D 1998. The inverted norm: the formation and functioning of racially-mixed congregations in South Africa. In M Cousineau (ed) Religion in a changing world. Greenwood: Westport, CT, pp. 69-79.

Villa-Vicencio, C 1988. Trapped in apartheid. A socio-theological history of the English-speaking churches. Maryknoll NY: Orbis.

Wallerstein, I 1990. Culture as the ideological battleground of the modern world-system. In Featherstone, M (ed) Global culture: nationalism, globalization and modernity. London: Sage, pp. 31-56.

Zaaiman, J 1994. Kerk en geloofsaffiliasie in Suid-Afrika [Church and religious affiliation in South Africa]. Nederduits Gereformeerde Teologiese Tydskrif 35 (4): 565574. 